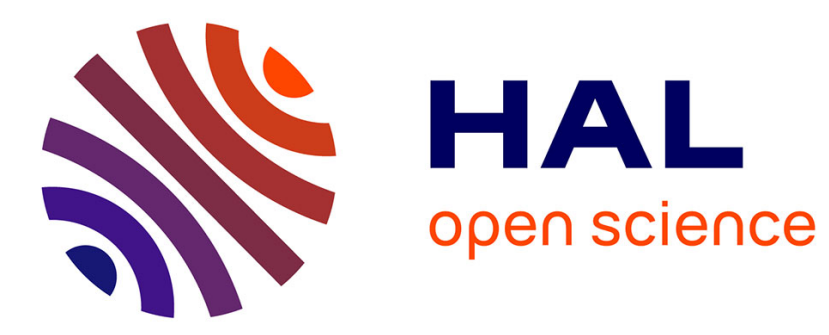

\title{
Does spatial population structure affect seed set in pollen-limited Thymus capitatus?
}

Thomas Tscheulin, Theodora Petanidou

\section{To cite this version:}

Thomas Tscheulin, Theodora Petanidou. Does spatial population structure affect seed set in pollenlimited Thymus capitatus?. Apidologie, 2011, 42 (1), pp.67-77. 10.1051/apido/2010035 . hal01003568

\section{HAL Id: hal-01003568 \\ https://hal.science/hal-01003568}

Submitted on 1 Jan 2011

HAL is a multi-disciplinary open access archive for the deposit and dissemination of scientific research documents, whether they are published or not. The documents may come from teaching and research institutions in France or abroad, or from public or private research centers.
L'archive ouverte pluridisciplinaire HAL, est destinée au dépôt et à la diffusion de documents scientifiques de niveau recherche, publiés ou non, émanant des établissements d'enseignement et de recherche français ou étrangers, des laboratoires publics ou privés. 


\title{
Does spatial population structure affect seed set in pollen-limited Thymus capitatus?**
}

\author{
Thomas Tscheulin, Theodora PETANIDOU \\ University of the Aegean, Department of Geography, University Hill, 81100 Mytilene, Greece
}

Received 30 August 2009 - Revised and accepted 29 January 2010

\begin{abstract}
Plant population size has been shown to affect insect visitation and reproductive success. Small populations are at risk because individuals are more likely to be affected by stochastic processes and inbreeding depression (Allee effect). Additionally, several studies have found that plants in small populations also experience lower pollinator visitation rates, which may further decrease reproduction. In this study, seed set, pollinator visitation and pollen limitation of Thymus capitatus (L.) was assessed in 32 patches in eight populations of various sizes on the island of Lesvos, Greece. All populations except one were significantly pollen-limited. We found that although free-pollinated flowers produced more seeds in larger populations this was not due to higher pollinator visitation rates as flowers which received pollen supplements also produced more seeds in larger populations. We hypothesize that the higher seed set is due to a generally greater genetic variability or better habitat quality. We show that honeybee visitation alone significantly decreases pollen limitation.
\end{abstract}

pollination / Thymus capitatus / Lesvos / population size / patch size / pollen limitation

\section{INTRODUCTION}

Habitat fragmentation is an increasing problem and profoundly threatens biodiversity in many ecosystems (Henle et al., 2004). As a result many plant populations become smaller, which can have serious implications for conservation (Brys et al., 2003).

Plant population size has been shown to affect demographics. Apart from the negative effects resulting from stochastic processes and genetic composition (e.g. Schemske et al., 1994; Spira, 2001; Severns, 2003; Leimu et al., 2006; Fox, 2007) the effects on plant population demographics are due to the fact that flowers in larger populations generally experience lower pollen limitation, and therefore, have higher seed set (Jennersten and Nilsson, 1993; Conner and Neumeier, 1995;

Corresponding author: T. Tscheulin, t.tscheulin@geo.aegean.gr

* Manuscript editor: Stan Schneider
Ågren, 1996; Brys et al., 2007). This can be due to pollinators in larger populations depositing less heterospecific pollen, which improves pollen quality (Jennersten and Nilsson, 1993), or to pollinators being generally more attracted to larger resources, which improves pollen quantity (Ågren, 1996). Small populations often provide less rewards (nectar and pollen) thereby failing to recruit sufficient numbers of resident pollinators (Rathcke, 1983; Klinkhamer and van der Lugt, 2004), have smaller, less attractive floral displays (Amarasekare, 2004; Ghazoul, 2005) or lower plant densities, and hence have higher withinplant movement of pollinators (Mustajärvi et al., 2001; Iwaizumi and Sakai, 2004).

Fundamental changes in landscape structure, and the domestication and concentration of colonies of honeybees by beekeepers, have the potential to disrupt the presumed ecological balance between native bee populations and honeybees (Steffan-Dewenter and Tscharntke, 2000). Honeybees have been 
Table I. Study populations of Thymus capitatus on the Greek island of Lesvos.

\begin{tabular}{|c|c|c|c|c|c|}
\hline \multirow{2}{*}{ Population } & \multirow{2}{*}{ Altitude ( $\mathrm{m}$ asl) } & \multicolumn{2}{|c|}{ Location } & \multirow{2}{*}{ Population area $\left(\mathrm{m}^{2}\right)$} & \multirow{2}{*}{$\begin{array}{c}\text { Population size (\# of } \\
\text { individuals) }\end{array}$} \\
\hline & & Latitude & Longitude & & \\
\hline University & 31 & $26^{\circ} 34^{\prime} 17^{\prime \prime} \mathrm{E}$ & $39^{\circ} 04^{\prime} 56^{\prime \prime} \mathrm{N}$ & 86 & $<1000$ \\
\hline Moria & 137 & $26^{\circ} 30^{\prime} 58^{\prime \prime} \mathrm{E}$ & $39^{\circ} 07^{\prime} 18^{\prime \prime} \mathrm{N}$ & 436 & $<1000$ \\
\hline Skala & 36 & $26^{\circ} 32^{\prime} 20^{\prime \prime} \mathrm{E}$ & $39^{\circ} 03^{\prime} 00^{\prime \prime} \mathrm{N}$ & 557 & $<1000$ \\
\hline Airport & 32 & $26^{\circ} 36^{\prime} 21^{\prime \prime} \mathrm{E}$ & $39^{\circ} 02^{\prime} 48^{\prime \prime} \mathrm{N}$ & 705 & $<1000$ \\
\hline Sifnaios & 75 & $26^{\circ} 36^{\prime} 13^{\prime \prime} \mathrm{E}$ & $39^{\circ} 02^{\prime} 16^{\prime \prime} \mathrm{N}$ & 924 & $>1000$ \\
\hline Pirgi & 78 & $26^{\circ} 32^{\prime} 05^{\prime \prime} \mathrm{E}$ & $39^{\circ} 04^{\prime} 37^{\prime \prime} \mathrm{N}$ & 1586 & $>1000$ \\
\hline Kudurudia & 80 & $26^{\circ} 30^{\prime} 57^{\prime \prime} \mathrm{E}$ & $39^{\circ} 03^{\prime} 30^{\prime \prime} \mathrm{N}$ & 1950 & $>1000$ \\
\hline Quarry & 64 & $26^{\circ} 32^{\prime} 39^{\prime \prime} \mathrm{E}$ & $39^{\circ} 05^{\prime} 38^{\prime \prime} \mathrm{N}$ & 3562 & $>1000$ \\
\hline
\end{tabular}

described as superior competitors because of: (1) the high requirements of nectar and pollen of their large perennial colonies compared to solitary bees; and (2) the rapid exploitation of attractive patches of flowering plants facilitated by their unique communication system (Visscher and Seeley, 1982; Steffan-Dewenter and Tscharntke, 2000).

The Mediterranean supports some of the most diverse plant-pollinator communities and is seen as a biodiversity hotspot (Michener, 2000). Pollen limitation is especially common in ecosystems with high plant species richness as a result of strong interspecific competition between plant species to attract pollinators (Vamosi et al., 2006). Therefore, habitat fragmentation has the potential to be even more detrimental in Mediterranean ecosystems.

Thymus capitatus (L.) is a cornucopious plant. It is rich in nectar resources and is visited by many different pollinator species (Petanidou and Vokou, 1993; Petanidou and Smets, 1995). To our knowledge T. capitatus has not been tested for pollen limitation. Given the reported high level of visitation to T. capitatus in Greece (Petanidou and Vokou, 1993) we do not expect this plant to be pollenlimited, but in case of actual pollen-limitation are interested to determine if pollen-limitation is related to population or patch size.

We systematically sampled $T$. capitatus flower visitors in eight populations on the Greek island of Lesvos, famous for its Thyme honey production, over three rounds during the flowering season in June and July 2006. We focus here on patch and population size, the tax- onomic groups of flower visitors, their impact on seed set, and competition for resources.

\section{MATERIALS AND METHODS}

\subsection{Study species}

Thymus capitatus is a perennial chamaephyte that occurs on dry hills, rocky places, roadsides and occasionally on waste ground or sand-dunes in sunny and dry places. It is a key species in Eastern Mediterranean phryganic systems (Petanidou and Smets, 1996; Blamey and Grey-Wilson, 2004). It flowers from May to July. Flowers are purplish or pink, 7-10 mm long and borne in terminal clusters (Petanidou and Vokou, 1993). They are insectpollinated and produce a maximum of four seeds.

\subsection{Populations and study design}

The study was carried out during the summer (June and July) of 2006 on the Greek island of Lesvos, which is situated in the North East Aegean. The island is $70 \mathrm{~km}$ long and $45 \mathrm{~km}$ wide at its longest and widest point. Eight sites were chosen in the southeastern part of the island (Tab. I) which is dominated by olive groves and, at higher altitudes, by pine forests (Kosmas et al., 2000). The study sites were a minimum of $1 \mathrm{~km}$ apart and the mean distance to the nearest population was $2.1 \mathrm{~km}$. Within each population four distinct patches of flowering $T$. capitatus plants were selected, each at a distance of 2-10 $\mathrm{m}$ from the other. The areas covered by patches and the areas covered by populations, hereafter called patch area and habitat area were determined as a measurement of 
patch and population size. The density of flowering plants per patch was determined by counting all flowering plants in a patch and dividing by patch area. The patch areas covered between 3.78 and $2629.88 \mathrm{~m}^{2}$ (average $288.78 \mathrm{~m}^{2}$ ) and contained flowering plant densities between 0.09 and $6.08 \mathrm{~m}^{-2}$ (average $1.31 \mathrm{~m}^{-2}$ ).

\subsection{Pollination treatments}

In order to obtain information on the plant breeding system and to test for pollen limitation, we subjected randomly selected flowers on randomly selected plants to pollination treatments once at the peak of the flowering period. In each patch of each population 10 plants were chosen. On each plant one flower was hand crossed with conspecific pollen from an individual situated at least $3 \mathrm{~m}$ away from the recipient, and one further flower was marked and left unmanipulated for open pollination. In addition, on a further 10 randomly selected plants in each patch, one open flower in previously bagged inflorescences was hand pollinated with self pollen, and one further flower was marked and left unmanipulated for spontaneous selfing in the "Quarry" population only, at the peak of the flowering period. The inflorescences were re-bagged subsequently. All hand pollinations consisted of a single application of an abundant quantity of pollen by carefully daubing the exposed anthers onto the pollen recipient's stigma. When the fruits were almost mature they were collected and the contained seeds counted. The number of fruits recovered from the different treatments was above $90 \%$ (collected $\mathrm{N}>$ 37 ) in all populations. The remaining marked fruits could not be found due to the continuous growth of the experimental plants and did therefore not enter the analysis.

\subsection{Flower observation}

Insect visitation observations to $T$. capitatus flowers were carried out over three rounds in each of the eight populations between 13/06/2006 and 20/07/2006 from 9.45 am to $4.00 \mathrm{pm}$ to determine the visitation rates of different taxonomic groups. The order of which the eight plant populations were visited was randomised in each round.

Pollinator observations were conducted over the course of one day per population and round in suitable weather conditions (temperature $>20{ }^{\circ} \mathrm{C}$, avoiding cloudy, rainy or windy weather). Each observation round per population consisted of two sets of four (in each patch) 15-min observations, one set in the morning and another set in the afternoon. The observations were carried out in subsets of each patch, hereafter called observation units. Observation units were set up new in each round and varied in shape and size, but always contained between 96 and 121 flowers. Observers kept a reasonable distance from the observation units and remained still for a few minutes before starting the observations. During each 15-min observation period, we recorded each insect that visited $T$. capitatus flowers within the observation unit and assigned it to one of four taxonomic groups: honeybees, other bees, hoverflies or other insects.

We pooled the observation data (i.e., the morning and the afternoon visitor counts) per round and patch and calculated the visitation rate as the mean number of visits to T. capitatus by the different taxonomic groups per flower and hour.

\subsection{Statistical analysis}

The predictor variables were taxonomic group (honeybee, other bee and other insect) visitation rates, patch area, population area and density of flowering plants per patch. The response variables were open pollination seed set, cross pollination seed set, $\Delta$ seed set (cross seed set - open pollination seed set), honeybee visitation rates and other bee visitation rates. The statistical analysis of the data was carried out using R, version 2.6.1. All response variables fulfilled the requirements of normality and homoscedasticity. We applied linear mixed effects models fitted by maximum likelihood using the "nlme function". For every response variable we constructed maximal models containing all predictor variables and their interactions. We then simplified the models using a stepwise backward elimination of the terms. Population identity entered the model as random factor to account for the nested design of patches being nested within populations. All other explanatory variables including their interactions entered the model as fixed factors. Only models based on predictor variables that were not significantly correlated were constructed. We used simple linear regressions in Figures 3-6 to graphically present the results of the mixed-models.

Mann-Whitney U tests were used in SPSS 15.0 to compare seed set of flowers that were left untreated, received pollen supplements from other 


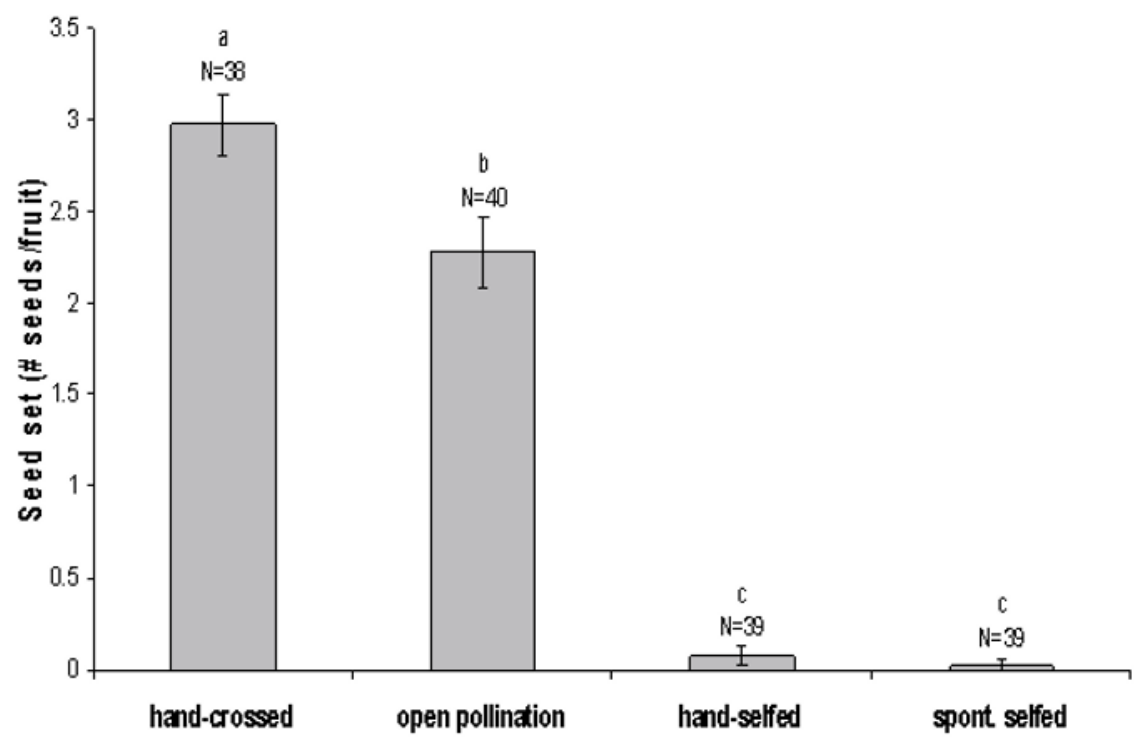

Figure 1. Seed set per fruit in the "Quarry" populations after hand-crossing, open (free) pollination, handselfing and spontaneous selfing. Different letters above bars indicate a significant difference between treatments (Mann-Whitney U tests).

individuals, were hand-selfed, and bagged in the "Quarry" population. Bonferroni corrections were applied.

Kruskal-Wallis tests were used in SPSS 15.0 to compare open pollination seed set and and cross seed set within each population.

\section{RESULTS}

\subsection{Pollination treatments}

Seed set in the spontaneous selfing and the hand-selfed treatments were significantly lower than in the free-pollinated flowers (Fig. 1). $\Delta$ seed set had positive values in all populations, which indicates general pollen limitation. In all populations but, one open pollination seed set was significantly lower than cross seed set (Fig. 2). Overall populations were strongly pollen-limited $(\mathrm{Z}=-7.192, P<$ $0.001)$.

\subsection{Flower visitation}

The populations of T. capitatus studied varied greatly in the area covered, ranging from 86 to $1950 \mathrm{~m}^{2}$.

A total of 1126 insects were recorded performing 12626 visits to 20582 available $T$. capitatus flowers in $48 \mathrm{~h}$ of observations. Honeybees accounted for 893 of the recorded insects $(79.3 \%)$ and 11386 of the observed flower visits $(90.2 \%)$. Other bees, hoverflies and remaining insects made up only 58, 8 and 167 of the visitors, respectively and performed 306,17 and 917 of the visits, respectively. Hoverflies' visitation rates were not included in the statistical analyses due to their low numbers.

Open pollination seed set was affected by honeybee visitation rate and population area and increased significantly with increasing honeybee visitation rates and increasing population area (Tab. II; Figs. 3, 4). Likewise cross seed set was significantly influenced by population area (Fig. 5). In order to exclude the 


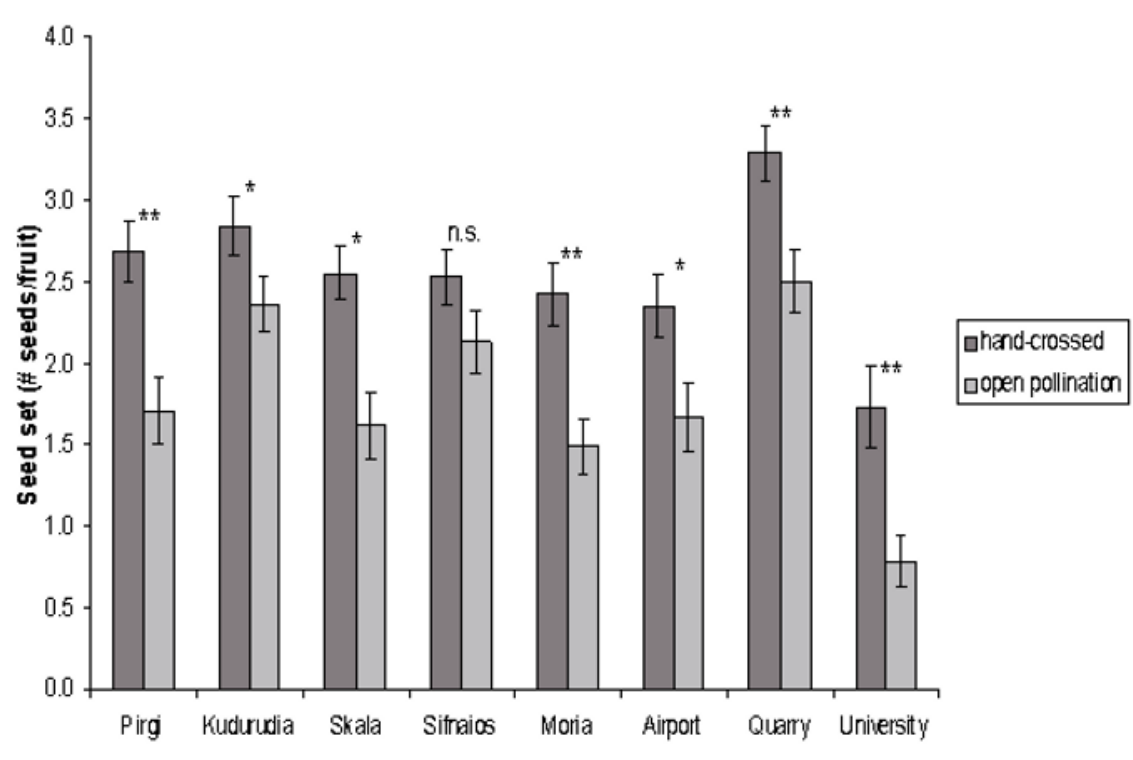

Figure 2. Number of seeds per fruit and population after hand-crossing and open pollination in eight populations. Stars above bars indicate a significant difference between treatments within the same population (*0.05>P $0.01, * * 0.01>P \geqslant 0.001$; Kruskal-Wallis tests).

Table II. Degrees of freedom and F-values of selected linear mixed effect models for 32 patches in 8 populations of Thymus capitatus. Honeybee visitation, other bee visitation, other insect visitation, patch and population area and flowering plant density entered the model as fixed factors and population identity as random factor. For every response variable we constructed maximal models containing all predictor variables and their interactions. We then simplified the models using a stepwise backward elimination of the terms. None of the interactions were significant. The variables in the top row are response variables, the variables in the first column are predictor variables $(* 0.05>P \geq 0.01$, ** $0.01>P \geq 0.001$; n.s. $=$ non-signifiant).

\begin{tabular}{|c|c|c|c|c|c|c|c|c|c|c|}
\hline & \multicolumn{2}{|c|}{$\begin{array}{c}\text { Open pollination } \\
\text { seed set }\end{array}$} & \multicolumn{2}{|c|}{ Cross seed set } & \multicolumn{2}{|c|}{ Delta seed set } & \multicolumn{2}{|c|}{$\begin{array}{l}\text { Honeybee } \\
\text { visitation }\end{array}$} & \multicolumn{2}{|c|}{$\begin{array}{l}\text { Other bee } \\
\text { visitation }\end{array}$} \\
\hline & d.f. & $\mathrm{F}$ & d.f. & $\mathrm{F}$ & d.f. & $\mathrm{F}$ & d.f. & $\mathrm{F}$ & d.f. & $\mathrm{F}$ \\
\hline Honeybee visitation & 1,23 & $4.45^{*}$ & & & 1,23 & $8.15^{* * * *}$ & & & n.s. & n.s. \\
\hline Other bee visitation & n.s. & n.s. & & & n.s. & n.s. & n.s. & n.s. & & \\
\hline $\begin{array}{l}\text { Other insect } \\
\text { visitation }\end{array}$ & n.s. & n.s. & & & n.s. & n.s. & n.s. & n.s. & n.s. & n.s. \\
\hline Patch area & n.s. & n.s. & n.s. & n.s. & n.s. & n.s & n.s. & n.s. & n.s. & n.s. \\
\hline $\begin{array}{l}\text { Population area } \\
\text { Patch flowering plant }\end{array}$ & 1,6 & $12.90^{*}$ & 1,6 & $14.19 * *$ & n.s. & n.s. & n.s. & n.s. & n.s. & n.s. \\
\hline density & n.s. & n.s. & n.s. & n.s. & n.s. & n.s. & n.s. & n.s. & n.s. & n.s. \\
\hline
\end{tabular}




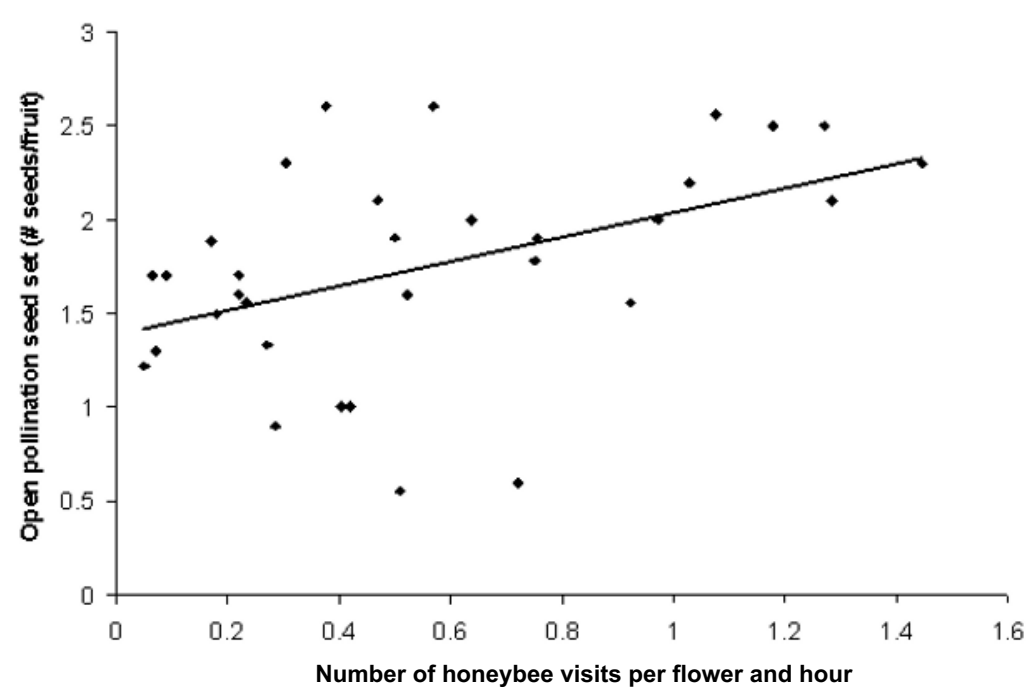

Figure 3. Relationship between open pollination seed set (\# seeds per fruit) and the number of honeybee visits per flower and hour for all patches $\left(\mathrm{F}_{1,23}=4.45^{*}\right)$.

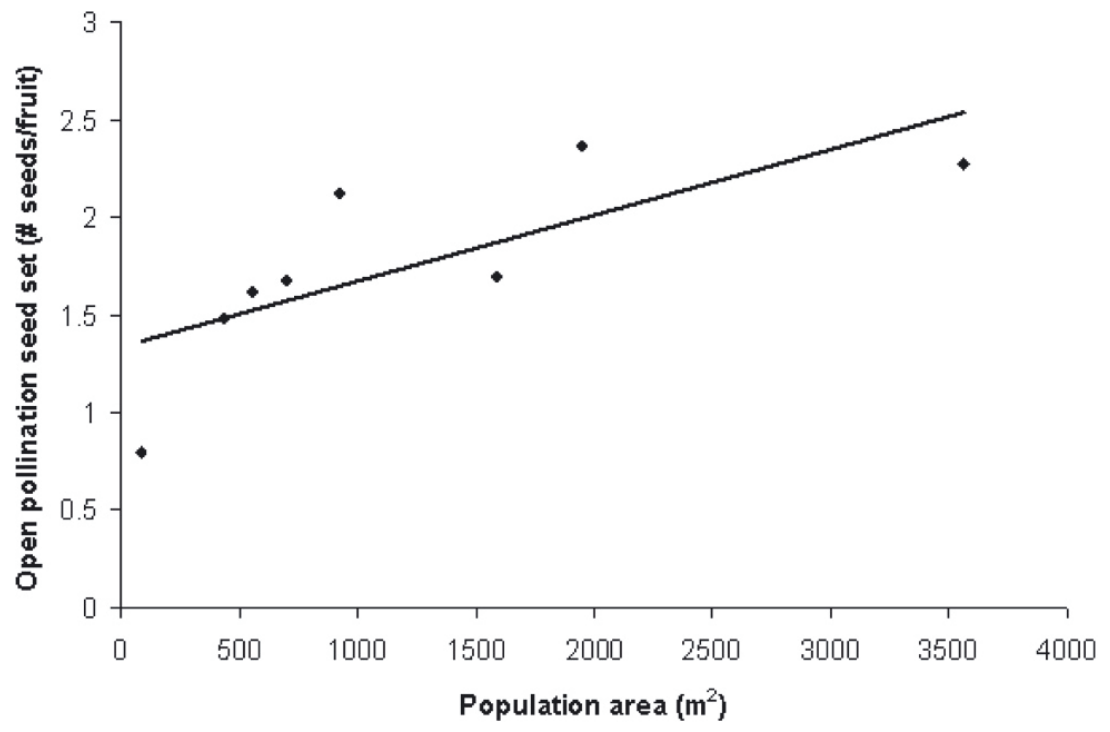

Figure 4. Relationship between open pollination seed set (\# seeds per fruit) and population area for all populations $\left(\mathrm{F}_{1,6}=12.90 *\right)$. 


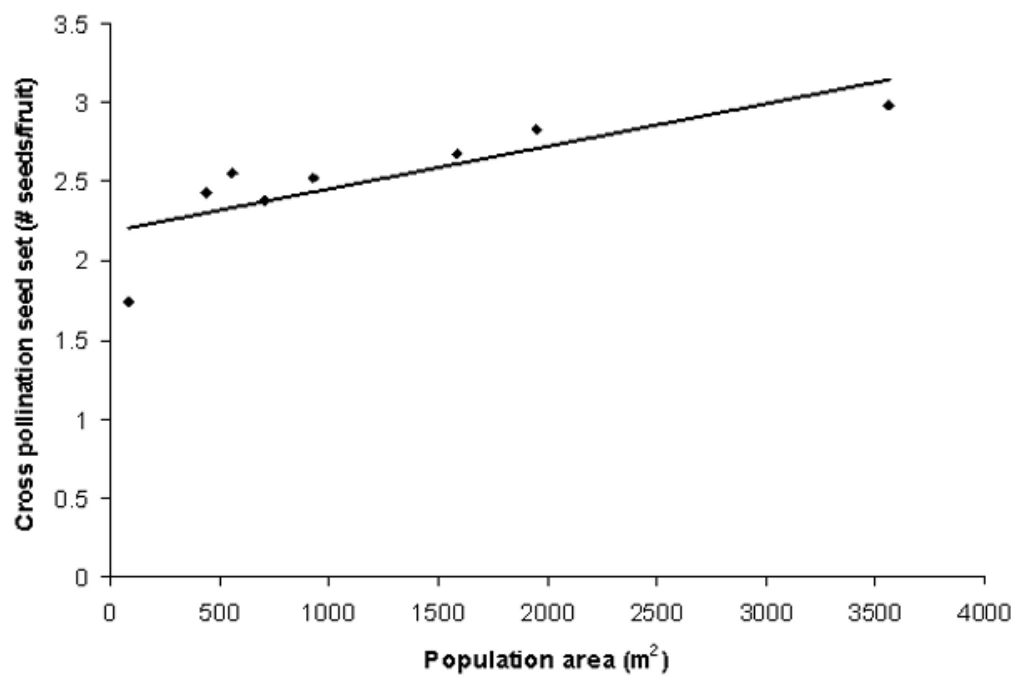

Figure 5. Relationship between cross pollination seed set (\# seeds per fruit) and population area for all populations $\left(\mathrm{F}_{1,6}=14.19 * *\right)$.

variance in the seed set data, which is not pollinator-dependent, we calculated $\Delta$ seed set by subtracting the averaged open pollination seed set from cross seed set for each patch. $\Delta$ seed set is a measurement of pollen limitation with positive values indicating actual limitation. $\Delta$ seed set was negatively influenced by honeybee visitation rates (Fig. 6). The visitation rates of the taxonomic groups were not influenced by any of the predictor variables used. None of the interactions in any of the models were significant.

\section{DISCUSSION}

\subsection{Flower visitation}

The fact that seed set in flowers which received supplementary pollen increased with population area suggests that there is an element other than pollinator visitation that impacts seed set. When we excluded the variance in the seed set data, which is not pollinatorrelated, by calculating $\Delta$ seed set (pollen limitation) and used this as response variable, habitat area and patch area had no more impact on seed set. This implies that we are probably dealing with a genetic effect because individuals in small populations are generally more likely to be related than in large populations, which may impact reproduction through inbreeding depression (Spira, 2001; Severns, 2003; Leimu et al., 2006). It could also be due to a generally lower habitat quality (i.e., climatic factors, soil quality, topography) associated with small populations (Campbell and Halama, 1993; Paschke et al., 2002), although we have no physical data to support this. Thus, contrary to previous studies, pollen limitation did not decrease with increasing population or patch area (e.g. Ågren, 1996). This could have resulted from the large foraging range of honeybees or the decision of the bee keepers to take advantage of even the smallest available flower resource. Wolf and Harrison (2001), who also reported no correlation between visitation rates and population size in Calystegia collina in California, and found an increase in seed set in larger populations, hypothesized that pollination success is related to the quality rather than the quantity of pollen deposited. 


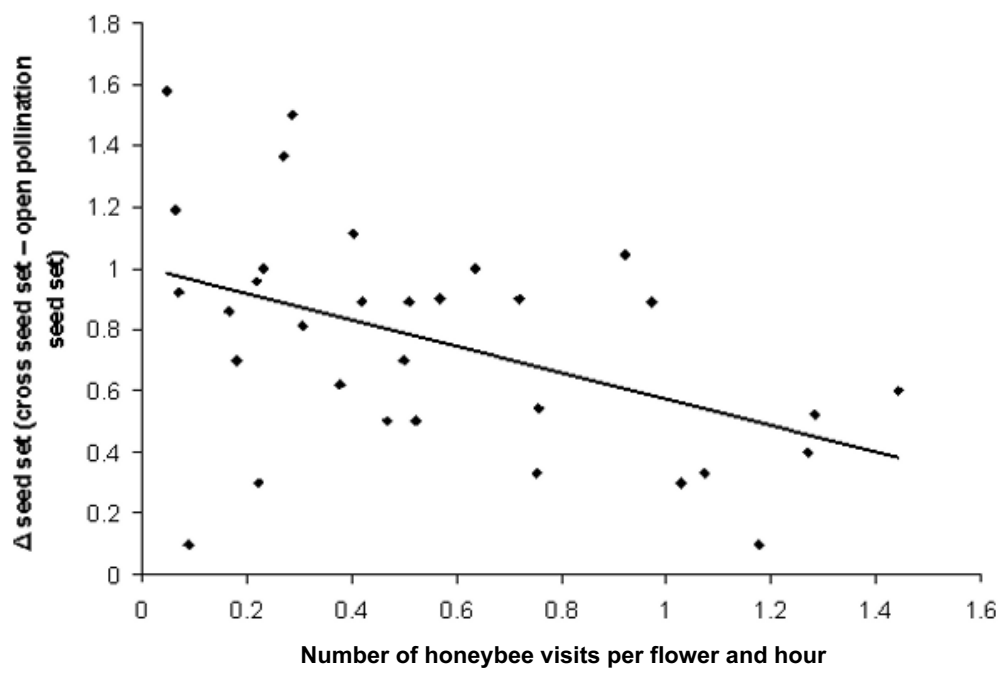

Figure 6. Relationship between $\Delta$ seed set, as a measurement of pollen limitation, and the number of honeybee visits per flower and hour in all patches $\left(\mathrm{F}_{1,23}=8.15^{* * *}\right)$.

This hypothesis is supported by Jennersten and Nilsson (1993), who found that pollinators in large populations deposit less heterospecific pollen. Wolf and Harrison (2001), however, related open pollination seed set and not pollen limitation to population size and might, therefore, unintentionally have measured habitat quality and genetic effects.

Our finding that patch and population area had no influence on visitation rates and pollen limitation may again be due to the large foraging range of honeybees, which made up the vast majority of visitors, and the fact that honeybee densities are to a large extent influenced by anthropogenic decisions (Steffan-Dewenter and Tscharntke, 2000).

Contrary to previous studies, honeybee visitation rates did not affect other bee visitation rates, but competition might nonetheless have had a major impact due to the overall high numbers of honeybees, i.e., no population of $T$. capitatus had low honeybee visitation rates (Steffan-Dewenter and Tscharntke, 2000; Spira, 2001; Walther-Hellwig et al., 2006). Because our visitation rates are based on coarse taxonomic groups and not on species we cannot say if honeybee visitation rates affected the overall bee diversity, which may in turn have influenced the other bee visitation rates and seed set.

\subsection{Pollination treatments}

Our results suggest that Thymus capitatus is self-incompatible. We observed very low seed set both in the spontaneous selfing and the hand-selfing treatment, which complies with results from our previous research (Petanidou, unpubl. data). Thymus capitatus is, therefore, dependent on insect pollination and outcrossing, which renders habitat fragmentation and the potential competition for floral resources between pollinators and its effect on bee diversity and seed set even more adverse.

We showed that all populations but one were significantly pollen-limited. Pollen limitation is especially common in ecosystems with high plant species richness as a result of strong interspecific competition between plant species to attract pollinators (Vamosi et al., 2006). Given the very high visitation rates generally experienced in the study populations, the result is nonetheless surprising. Honeybees may visit $T$. capitatus flowers primarily 
for their nectar, which constitutes an important and consistent source of water and nutrients in the Eastern Mediterranean phrygana (Petanidou and Vokou, 1993). This is especially likely as in Labiatae pollen quantity is very limited and nectar is the principal floral reward (Petanidou and Vokou, 1993). It has been pointed out that nectar foraging honeybees learn to avoid, to a large degree, the contact with pollen, thereby often neglecting pollination (Westerkamp, 1991). Pollen avoidance by honeybees could have led to the pollen limitation we found, despite the relatively high visitation rates.

In addition, it has been shown before that pollinator diversity rather than abundance increases seed set (Klein et al., 2003a, b). The pollen limitation in our study populations despite high overall visitation rates might therefore be due to the low bee diversity, which may be driven by the high honeybee visitation rates.

\subsection{Conclusions}

All populations except one were significantly pollen-limited. Although freepollinated flowers produce more seeds in larger populations this is not due to higher levels of visitation as flowers which received pollen supplements showed the same phenomenon. We hypothesize that the increase in seed set is due to a generally higher genetic variability or better habitat quality. By relating the predictor variables to a measurement of pollen limitation we show that honeybee visitation alone significantly decreased pollen limitation. Honeybee visitation rates did not affect other bee visitation rates but competition might nonetheless have had a major impact due to the overall high numbers of honeybees. Neither population nor patch area significantly influenced pollen limitation.

\section{ACKNOWLEDGEMENTS}

Thomas Tscheulin was funded by the EUEuropean Social Fund (80\%), and the Greek Ministry of Development-GSRT (20\%). The research project was financed by the EC within the FP 6 Integrated Project ALARM (GOCECT-2003-506675) [Assessing LArge-scale environmental Risks for biodiversity with tested Methods; http://www.alarmproject.net; Settele et al., 2005]. We thank Charalambos Petsikos for his help with collecting the field data and Andrew Grace for the identification of the insects. We would also like to thank two anonymous reviewers for their valuable comments and suggestions.

La production de graines est-elle affectée par la structure spatiale de la population chez Thymus capitatus avec une faible quantité de pollen disponible?

Thymus capitatus / pollinisation / Lesvos / Grèce / taille de la population / taille du patch / limitation en pollen

Zusammenfassung - Beeinflusst die räumliche Populationsstruktur die Samenmenge bei pollenlimitiertem Thymus capitatus? Es wurde nachgewiesen, dass die Populationsgröße von Pflanzen auch deren demographische Entwicklung beeinflusst. Dies könnte daran liegen, dass $\mathrm{Be}-$ stäuber in größeren Populationen weniger Pollen von anderen Pflanzenarten deponieren, wodurch die Pollenqualität verbessert wird; Bestäuber könnten aber auch grundsätzlich von den größeren Ressourcen stärker angelockt werden, wodurch sich die Pollenquantität erhöhen würde. In dieser Untersuchung werden die Samenmenge, die Besuche durch Bestäuber und die Pollenlimitierung von Thymus capitatus (L.) auf der Insel Lesbos in Griechenland evaluiert. Angesichts der beschriebenen hohen Frequenz an Bestäuberbesuchen bei $T$. $\mathrm{ca}$ pitatus in Griechenland gingen wir davon aus, dass diese Pflanze nicht pollenlimitiert ist. Sollte aber tatsächlich eine Pollenlimitierung nachgewiesen werden, wollten wir herausfinden, ob diese von der Populations- oder Patchgröße abhängt.

Wir erfassten auf der Insel Lesbos systematisch die Blütenbesucher von T. capitatus bei acht Populationen. Innerhalb jeder Population wurden vier unterschiedliche Patches von blühenden T. capitatusPflanzen ausgewählt. Die von den Patches bedeckten bzw. von den Populationen besiedelten Flächen wurden als Messwerte für die Patch- und Populationsgrößen verwendet. Für die Versuche wurden zufällig ausgewählte Pflanzen künstlich bestäubt. Dazu wurden in jedem Patch von jeder Population 10 Pflanzen ausgewählt und danach per Hand auf jeweils einer Blüte von jeder Pflanze konspezifischer Pollen übertragen; eine weitere Blüte von jeder Pflanze wurde markiert und diente als unmanipulierte Kontrolle für natürliche Bestäubung. $\mathrm{Zu}-$ sätzlich wurden bei weiteren 10 zufällig ausgewählten Pflanzen aus jedem Patch jeweils eine offene 
Blüte eines zuvor eingesackten Blütenstandes per Hand mit eigenem Pollen bestäubt; eine weitere Blüte wurde markiert und verblieb ohne weitere Manipulation für spontane Selbstung. Alle Handbestäubungen bestanden aus einer einzigen Applikation einer ausreichenden Menge an Pollen, indem vorsichtig die offenen Antheren auf die Pollen aufnehmenden Stigmata verschmiert wurden.

Alle Populationen waren mit einer Ausnahme signifikant pollenlimitiert. Obwohl natürlich bestäubte Blüten in großen Populationen mehr Samen produzierten, war dies kein Effekt einer höheren Anzahl an Blütenbesuchen, da Blüten, die zusätzlich Pollen erhielten, dasselbe Phänomen zeigten. Wir vermuten vielmehr, dass die Zunahme bei der Samenmenge durch die insgesamt höhere genetische Variabilität oder durch die bessere Habitatqualität verursacht wird. Indem wir die prognostizierten Variablen mit den Messungen zur Pollenlimitierung verknüpften, konnten wir zeigen, dass bereits die Honigbienenbesuche allein die Pollenlimitierung reduzierten. Die Honigbienenbesuche hatten keinen Einfluss auf die Besuche anderer Bienenarten, jedoch könnte Konkurrenz trotzdem aufgrund der insgesamt hohen Anzahl an Honigbienen einen bedeutenden Einfluss haben. Weder die Populations- noch die Patchflächen hatten einen signifikanten Effekt auf die Pollenlimitierung.

\section{Bestäubung / Thymus capitatus / Lesbos / Popu- lationsgröße / Patchgröße / Pollen}

\section{REFERENCES}

Ågren J. (1996) Population Size, pollinator limitation, and seed set in the self- incompatible herb Lythrum Salicaria, Ecol. Lett. 77, 1779-1790.

Amarasekare P. (2004) Spatial dynamics of mutualistic interactions, J. Anim. Ecol. 73, 128-142.

Blamey M., Grey-Wilson C. (2004) Wild Flowers of the Mediterranean, A \& C Black, London.

Brys R., Jacquemyn H., De Bruyn L., Hermy M. (2007) Pollination success and reproductive output in experimental populations of the selfincompatible Primula vulgaris, Int. J. Plant Sci. $168,571-578$.

Brys R., Jacquemyn H., Endels P., Hermy M., De Blust G. (2003) The relationship between reproductive success and demographic structure in remnant populations of Primula veris, Acta Oecol. 24, 247-253.

Campbell D., Halama J. (1993) Resource and pollen limitation to lifetime seed production in a natural plant population, Ecology 74, 1043-1051.
Conner J.K., Neumeier R. (1995) Effects of black mustard population size on the taxonomic composition of pollinators, Oecologia 104, 218-224.

Fox L.R. (2007) Climatic and biotic stochasticity: disparate causes of convergent demographies in rare, sympatric plants, Conserv. Biol. 21, 1556-1561.

Ghazoul J. (2005) Pollen and seed dispersal among dispersed plants, Biol. Rev. 80, 413-443.

Henle K., Lindenmayer D.B., Margules C.R., Saunders D.A., Wissel C. (2004) Species survival in fragmented landscapes: where are we now? Biodivers. Conserv. 13, 1-8.

Iwaizumi M.G., Sakai S. (2004) Variation in flower biomass among nearby populations of Impatiens textori (Balsaminaceae): effects of population plant densities, Can. J. Bot. 82, 563-572.

Jennersten O., Nilsson S.G. (1993) Insect flower visitation frequency and seed production in relation to patch size of Viscaria vulgaris (Caryophyllaceae), Oïkos 68, 283-292.

Klein A.M., Steffan-Dewenter I., Tscharntke T. (2003a) Fruit set of highland coffee increases with the diversity of pollinating bees, Proc. R. Soc. Lond. B Biol. Sci. 270, 955-961.

Klein A.M., Steffan-Dewenter I., Tscharntke T. (2003b) Pollination of Coffea canephora in relation to local and regional agroforestry management, J. Appl. Ecol. 40, 837-845.

Klinkhamer P.G.L., van der Lugt P.-P. (2004) Pollinator service only depends on nectar production rates in sparse populations, Oecologia 140, 491-494.

Leimu R., Mutikainen P., Koricheva J., Fischer M. (2006) How general are positive relationships between plant population size, fitness and genetic variation? J. Ecol. 94, 942-952.

Michener C.D. (2000) The Bees of the World, Johns Hopkins University Press, Baltimore, USA.

Mustajärvi K., Siikamaki P., Rytkonen S., Lammi A. (2001) Consequences of plant population size and density for plant-pollinator interactions and plant performance, J. Ecol. 89, 80-87.

Paschke M., Abs C., Schmid B. (2002) Relationship between population size, allozyme variation, and plant performance in the narrow endemic Cochlearia bavarica, Conserv. Genet. 3, 131-144.

Petanidou T., Smets E. (1995) The potential of marginal lands for apiculture: nectar secretion in Mediterranean shrublands, Apidologie 26, 39-52.

Petanidou T., Smets E. (1996) Does temperature stress induce nectar production in Mediterranean plants? New Phytol. 133, 513-518.

Petanidou T., Vokou D. (1993) Pollination ecology of Labiatae in a phryganic (East Mediterranean) ecosystem, Am. J. Bot. 80, 892-899. 
Rathcke B. (1983) Competition and facilitation among plants for pollination, Pollination Biol. 305-329.

Schemske D.W., Husband B.C., Ruckelshaus M.H., Goodwillie C., Parker I.M., Bishop J.G. (1994) Evaluating approaches to the conservation of rare and endangered plants, Ecology 75, 584-606.

Severns P. (2003) Inbreeding and small population size reduce seed set in a threatened and fragmented plant species, Lupinus sulphureus ssp. kincaidii (Fabaceae), Biol. Conserv. 110, 221-229.

Spira T.P. (2001) Plant-pollinator interactions: A threatened mutualism with implications for the ecology and management of rare plants, Nat. Areas J. 21, 78-88.

Steffan-Dewenter I., Tscharntke T. (2000) Resource overlap and possible competition between honey bees and wild bees in central Europe, Oecologia 122, 288-296.
Vamosi J.C., Knight T.M., Steets J.A., Mazer S.J., Burd M., Ashman T.L. (2006) Pollination decays in biodiversity hotspots, Proc. Natl. Acad. Sci. USA 103, 956-961.

Visscher P.K., Seeley T.D. (1982) Foraging strategy of honeybee colonies in a temperate deciduous forest, Ecology 63, 1790-1801.

Walther-Hellwig K., Fokul G., Frankl R., Buchler R., Ekschmitt K., Wolters V. (2006) Increased density of honeybee colonies affects foraging bumblebees, Apidologie 37, 517-532.

Westerkamp C. (1991) Honeybees are poor pollinators - why? Plant Syst. Evol. 177, 71-75.

Wolf A.T., Harrison S.P. (2001) Effects of habitat size and patch isolation on reproductive success of the serpentine morning glory, Conserv. Biol. 15, 111121. 